\title{
BAGIAN BAPAK SEPERTIGA DALAM KHI PASAL 177 MERUPAKAN KONSEKWENSI DARI BAGIAN IBU THULUTH AL-BÂQ; ANALISIS IJTIHAD ‘UMAR BIN KHATṬ̂̂AB
}

\author{
Syuhada' \\ Institut Agama Islam Bani Fattah Jombang, Indonesia \\ E-mail: rokhinsadja@gmail.com
}

\begin{abstract}
Instructions Qur'an about inheritance was so standard and tawqifiyat. But there is still very limited and in the form of global instructions. The designation rules in global situation give open space to make ijtihâd. In the case of the mother part being with father and one of husband or wife has never happened in the past Apostles led to 'Umar bin Khațtâb as caliph must make ijtihâd to give answers to completion. With this decision the mother part can be solved by maintaining the scale of two proportionate one for men and women by directing the understanding that the third part of mother on the condition it is third the rest of the treasure, not a third of the entire inheritance. However, when position of the father is not there, while his grandfather still exist and replace father in inheritance mother still get a piece a third of the inheritance because his grandfather is not equal to mother in inheritance. Part mother third of remainder having taken part husband in the case of above is to give the rule of law and consequences on the part of father become third though referred to inherit the remainder.
\end{abstract}

Keywords: Third Part of Father, Clause 177 KHI, Thuluth al-Bâq, Ijtihâd 'Umar bin Khațtâb 


\section{Pendahuluan}

Farâid atau dikenal dengan nama waris dalam Islam adalah membahas atau mengatur tentang berbagai macam hal dalam pembagian harta peninggalan kepada yang berhak menerimanya atas dasar ketentuan yang telah ditetapakan dalam kitab Allah swt, sunnah Nabi saw. dan kesepakatan ulamâ'. ${ }^{1}$ Pembuat ilmu farâ'ị atau waris Islam adalah Allah swt. Obyeknya adalah pembagian harta peninggalan kepada ahli waris yang berhak menerima. Faidahnya dengan ilmu tersebut, adalah dapat memberikan hak ahli waris atas harta peninggalan sesuai dengan tuntunan syariat Islam berdasarkan Al-Qur'an, al-Hadîth, al-'Ijmâ' dan alQiyâs. Waris dalam Islam disamping memuat aturan hukum mengenai perpindahan harta milik mayat secara definitif dan bermuatan paket murni dari Allah SWT (tauqîfi), itulah sebabnya ayat Al-Qur'an yang menjelaskan tentang waris tidak banyak, hanya tiga tempat saja yang mengatur secara rinci, detail, dan jelas, yaitu:

Pertama, Surat al-Nisâ'; 11 yang menjelasan bagian anak laki-laki dan anak perempuan (walad) dan yang menjelaskan bagian orang tua (bapakibu).

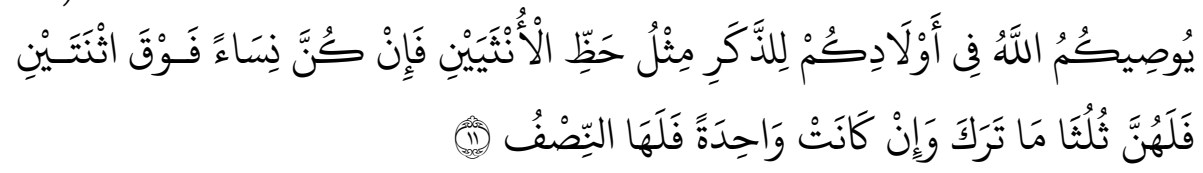

Artinya: "Allab mensyari'atkan bagimu tentang (pembagian pusaka untuk) anakanakmu. Yaitu bahagian seorang anak lelaki sama dengan babagian dua orang anak perempuan. Jika anak itu semuanya perempuan lebih dari dua, maka bagi mereka dua pertiga dari harta yang ditinggalkan. Jika anak perempuan itu seorang saja, maka ia memperoleh setengah harta." (QS. al-Nisâ’: 11). ${ }^{2}$

Shahabat Zaid bin Thâbit ra. berkata, apabila laki-laki atau perempuan meninggal dan meninggalkan seorang anak perempuan maka bagiannya $1 / 2$ dan jika meninggalkan dua orang anak atau lebih bagian mereka $2 / 3$. $^{3}$ Cucu laki-laki dari anak laki-laki disamakan dengan anak laki-laki, jika mayat tidak meninggalkan anak laki-laki. Dan cucu perempuan dari anak laki-laki disamakan dengan anak perempuan, jika mayat tidak meninggalkan anak

\footnotetext{
1 Muhammad al-Zuhailî, Al-Farẩị wa al-Mawârith wa al-Wasâyâ, Cet. 1 (Bairut: Dar alQalam at-Thayyib, 2001), 55.

2 Departemen Agama Republik Indonesia, Al-Qur'an dan Terjemahnya (Jakarta: Yayasan Penyelenggara Penterjemah atau Pentafsir al-Qur'an, 1971), 116

3 Abî 'Abdillâh M. bin Ismâ’il al-Bukhârî, Matn Șahîh al-Bukhârî, (Singapura: t.p, t.th), 165
} 
perempuan. Sebab kata walad mencakup anak, cucu, dan cicit. Sebagaimana kesepakatan ulama' fiqih.

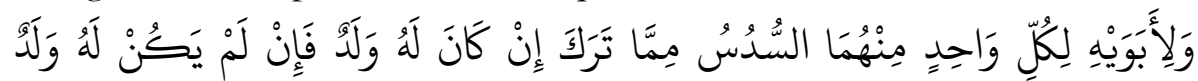

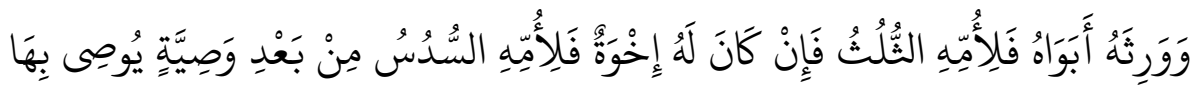

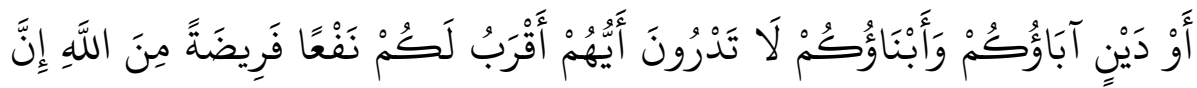

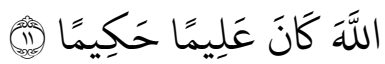

Artinya: "Dan untuk dua orang ibu bapak, bagi masing-masing seperenam dari harta yang ditinggalkan, jika yang meninggal itu mempunyai anak, jikea orang yang meninggal tidak mempunyai anak dan ia diwarisi oleh ibubapaknya (saja), maka ibunya mendapat sepertiga, jika yang meninggal itu mempunyai beberapa saudara, maka ibunya mendapat seperenam, (pembagian-pembagian tersebut di atas) sesudah dipenubi wasiat yang ia buat atau (dan) sesudah dibayar hutangnya. (Tentang) orang tuamu dan anak-anakmu, kamu tidak mengetabui siapa di antara mereka yang lebih dekat (banyak) manfa'atnya bagimu. Ini adalah ketetapan dari Allah. Sesunggubnya Allah Maha Mengetahui lagi Maha Bijaksana." (QS. Al-Nisâ': 11). ${ }^{4}$

Kedua, Surat al-Nisâ': 12 yang menjelaskan (a) bagian suami atau duda; (b) bagian janda atau beberapa janda; dan (c) bagian saudara seibu (lakilaki dan perempuan).



Artinya: "Dan bagimu (suami-suami) seperdua dari harta yang ditinggalkan oleh istri-istri mu, jika mereka tidak mempunyai anak, jika istri-istrimu itu mempunyai anak, maka kamu mendapat seperempat dari harta yang ditinggalkannya sesudah dipenubi wasiat yang mereka buat atau (dan) sesudah dibayar hutangnya." (QS. al-Nisâ': 12).

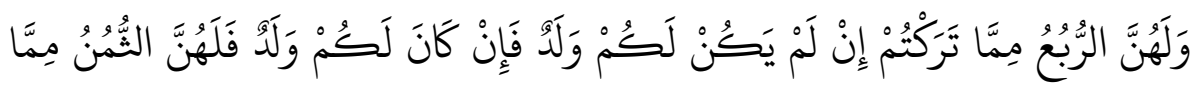

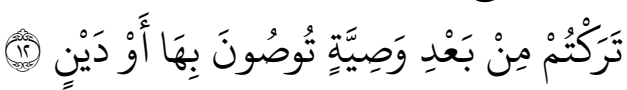

Artinya: "Para istri memperoleh seperempat dari harta yang kamu tinggalkan, jikea kamu tidak mempunyai anak, jika kamu mempunyai anak, maka

4 Departemen Agama, Al-Qur'an, 117.

5 Departemen Agama, Al-Qur'an, 117.

105 Syuhada' - Bagian Bapak Sepertiga Dalam KHI Pasal 177 
para istri mendapat seperdelapan dari harta yang kamu tinggalkan sesudah dipenubi wasiat yang kamu buat atau (dan) sesudah dibayar butang-butangmu." (QS. al-Nisâ’: 12). ${ }^{6}$

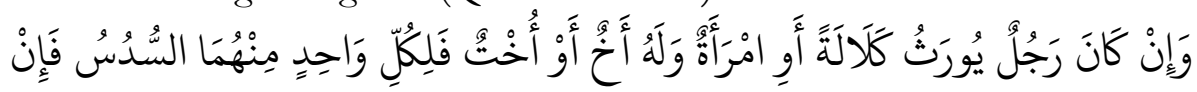

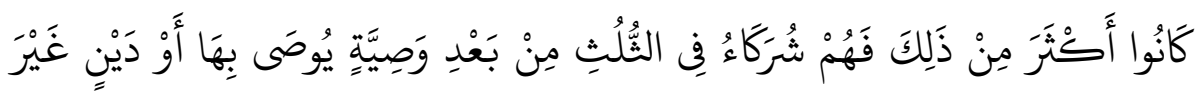

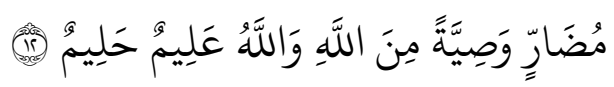

Artinya: "Tika seorang mati, baik laki-laki maupun perempuan yang tidak meninggalkan ayah dan tidak meninggalkan anak, tetapi mempunyai seorang saudara laki-laki (seibu saja) atau seorang saudara perempuan (seibu saja) maka bagi masing-masing dari kedua jenis saudara itu seperenam harta. Tetapi jika saudara-saudara seibu itu lebih dari seorang, maka mereka bersekutu dalam yang sepertiga itu, sesudah dipenubi wasiat yang dibuat olehnya dengan tidak memberi mudharat (kepada abli waris). (Allah menetapkan yang demikian itu sebagai) sebagai syari'at yang benar-benar dari Allah, dan Allah Maba Mengetahui lagi Maha Penyantun." (QS. al-Nisâ': 12). ${ }^{7}$

Ketiga, Surat al-Nisâ': 176 yang menjelaskan bagian saudara sekandung (laki-laki dan perempuan)

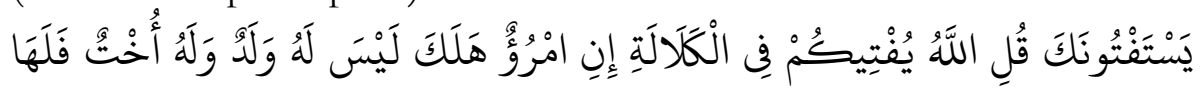

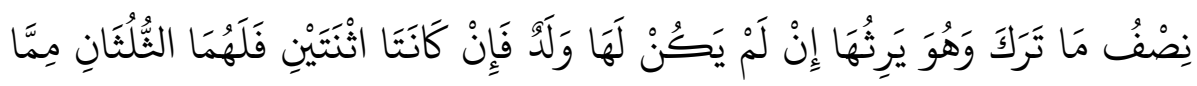

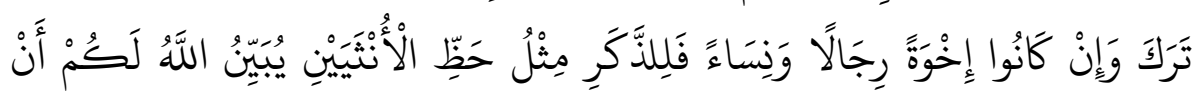

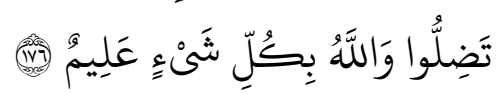

Artinya: "Mereka mintak fatwa kepadamu tentang (kalâlah). Katakanlah "Allah memberi fatwa kepadamu tentang kalala (yaitu): Jika seorang meninggal dunia, dan ia tidak mempunyai anak dan mempunyai saudara perempuan, maka bagi saudaranya yang perempuan itu seperdua dari harta yang ditinggalkannya, dan saudaranya yang laki-laki mempusakai (selurub barta saudara perempuan), jike ia tidak mempunyai anak; tetapi jika saudara perempuan itu dua orang, maka bagi keduanya dua pertiga dari harta yang ditinggalkan oleh yang meninggal. Dan jika mereka (abli waris itu terdiri dari) saudara-saudara laki-laki dan perempuan, maka

${ }^{6}$ Departemen Agama, Al-Qur'an, 117.

${ }^{7}$ Departemen Agama, Al-Qur'an, 117.

Tafaqquh-Volume 4, Nomor 2, Desember 2016 
bagian seorang saudara laki-laki sebanyak bahagian dua orang saudara perempuan. Allah menerangkan (bukum ini) kepadamu, supaya kamu tidak sesat. Dan Allah Maha Mengetahui segala sesuatu.” (QS. alNisâ': 176). ${ }^{8}$

Islam memandang harta adalah milik Allah SW'T semata, sedangkan manusia ditunjuk sebagai penguasanya. Begitu orang yang diamanati dan yang dititipi itu meninggal dunia, maka, harta kembali ke menjadi milik Allah swt secara otomatis. Oleh karena itu Allah swt. berhak ikut mengatur harta yang ditinggalkan oleh pemiliknya, paling tidak Allah swt mewakili mayat sebagai pemilik yang sudah tidak berdaya. Aturan yang ditetapkan oleh Allah swt adalah diberikan kepada keluarga yang ditunjuk dengan aturan wahyu. Dalam Fiqh Islam dikenal empat sebab milik yaitu; al-aqd (transaksi), tawallud min al-milk (perkembangan harta milik) dan iḅâz al-mubâhat (eksplorasi dari ruang kepemilikan umum), dan al-khalâfiyah atau irthun (penerusan kepemilikan atau warisan). Zakariya al-Anșârî menyebut ada sebab umum dan ada pula sebab khusus dalam hal mendapatkan harta secara balâl dari sisi khalâfiyah (penerusan kepemilikan) dengan media pewarisan. Sebab umum dimana seseorang berhak mendapat warisan adalah beragama Islam. ${ }^{9}$ Sedangkan sebab khusus cara mendapatkan harta secara halâl dalam kbalâfiyah (penerusan kepemilikan) dengan media pewarisan adalah; (a) hubungan kerabat khusus, yang mempunyai hubungan darah dengan mayat; (b) melangsungkan akad pernikahan secara sah menurut syari'at Islam dan statusnya hanya sebagai suami mayat atau istrinya mayat; dan (c) waris walâ' atau mendapatkan warisan karena memerdekakan budak, disebut juga dengan nasb al-buk $m,{ }^{10}$

Al-Qur'an merupakan acuan pertama hukum dan penentuan pembagian waris. Bahkan tidak ada ketentuan hukum lain yang sebegitu baku dalam AlQur'an seperti halnya dalam persoalan hukum waris. Hanya saja, dalam teks alKitâb dan al-Sunnah mengenai ketentuan waris sangat terbatas dan global sekali. Hanya sedikit saja dari hukum-hukum waris yang ditetapkan oleh Sunnah Nabi atau dengan ijtihâd para ulama' (fuqahâ'). Meski demikian ruang ijtihâd tetap terbuka. Misalnya Nabi yang belum memberikan keterangan jelas mengenai persoalan kalâlah yang disebut oleh al-Nisâ': 12 dan al-Nisâ': 176. Sangat diperlukannya tehnik akan rasionalisasi yang tertumpu pada ketajaman ijtihâd. Maka, banyak pandangan perihal pembagian waris antara seorang sahabat Nabi dengan lainnya. Muncul istilah gharrâwain atau umariyatain atas kecemerlangan ijtihâd 'Umar bin al-Khațâb dalam kasus waris. Ada juga kasus yang diselesaikan dengan kejeniusan pemikiran Zaid bin Thâbit yang dikenal sebagai sahabat yang oleh Nabi ditunjuk secara khusus sebagai pakar farâid dalam kasus mushârakah

8 Departemen Agama, Al-Qur'an, 153

9 Zakariyâ al-Anșârî, Șarh al-Taḅrîr (Surabaya: Maktabat Salim b. Sa'ad b. Nabhan, t.th), 86-87.

${ }^{10}$ Aḥmad 'Abd al-Jawad, Usûl al-Tlm al-Mawârith, Cet. II (Beirut: Dar al-Jil, 1986), 1-2. 
dan aqdariyah, dan berbagai kasus lain. Demikian juga saat masalah waris telah jatuh dibelantara pemikiran para mujtahid pasca sahabat. Meski begitu tidak satupun yang mempermasalahkan pembagian pokok yang telah ditentukan nasss semisal; setengah, seperempat, dan seperdelapan, duapertiga, sepertiga, dan seperenam.

Dalam tulisan ini akan dibahas mengenai bagian bapak sepertiga dalam KHI merupakan konsekwensi bagian ibu thuluth al-bâq (sepertiga dari sisa harta setelah diambil sebagai bagian suami). Pada bagian lain, dalam seluruh penyebutan bagian pasti dalam waris pada bagian; setengah, seperempat, dan seperdelapan, duapertiga, sepertiga, dan seperenam seluruhnya dipahami dengan sepersekian dari seluruh harta peninggalan dan bukan sepersekian dari seluruh sisa harta.

\section{Ayat-ayat yang Menjelaskan Waris}

Ayat-ayat yang menjelaskan tentang dasar hukum waris di atas, yaitu; surat al-Nisâ' ayat 11 , ayat 12 , dan ayat 176 memberikan pondasi dalam pembagian warisan, bahwa bagian perempuan separuh dari bagian lakilaki. Disamping itu ayat-ayat tersebut juga menyebutkan masing-masing ahli waris beserta status mereka. Sebagaimana urian sebagai berikut:

Pertama, Surat an-Nisa' ayat 11 yang menjelasan bagian anak perempuan separuh dari bagian anak laki-laki. Contoh kasus, ada seorang laki-laki atau perempuan meninggal dunia meninggalkan dua anak (perempuan dan laki-laki).

\begin{tabular}{|c|c|l|l|}
\hline \multicolumn{2}{|c|}{ Ahli waris } & Asal Masalah (AM) $: 3$ & Bagian ahli waris \\
\hline \hline 1 & Anak perempuan & $\begin{array}{l}\text { Seluruh } \\
\text { harta peninggalan }\end{array}$ & 1 bagian \\
\cline { 4 - 4 } 2 & Anak perempuan & 2 bagia \\
\hline
\end{tabular}

Penjelasan:

Bilangan 3 menjadi asal masalah, angka 3 dari banyaknya ahli waris perempuan dihitung seorang dan laki-laki dua orang. Misalkan harta peninggalan $\mathrm{Rp}$ 30.000.0000, maka bagian masing-masing:

\begin{tabular}{|c|l|c|l|}
\hline \multicolumn{2}{|c|}{ Ahli waris } & Bagian diterima & \multicolumn{1}{|c|}{ Keterangan : } \\
\hline 1 & $\begin{array}{l}\text { Anak } \\
\text { perempuan }\end{array}$ & Rp 10.000 .000 & $\begin{array}{l}\text { Bagian anak perempuan } \\
\text { separuh dari bagian anak } \\
\text { laki-laki }\end{array}$ \\
\hline 2 & $\begin{array}{l}\text { Anak } \\
\text { perempuan }\end{array}$ & Rp 20.000.000 \\
\hline
\end{tabular}

Kedua, Surat an-Nisa' ayat 11 yang menjelasan bagian orang tua (Ibu dan Bapak). Contoh kasus, ada seorang laki-laki atau perempuan 
meninggal dunia meninggalkan orang tua (ibu dan bapak). Bagiannya adalah :

\begin{tabular}{|c|l|l|l|}
\hline \multicolumn{2}{|c|}{ Ahli waris } & AM : 3 & \multicolumn{1}{c|}{ Bagian ahli waris } \\
\hline \hline 1 & Ibu & $1 / 3$ & 1 bagian \\
\hline 2 & Bapak & Sisa & 2 bagia \\
\hline
\end{tabular}

Penjelasan:

Bilangan 3 menjadi asal masalah, angka 3 dari penyebut bagian pasti. Misalkan harta peninggalan Rp 30.000.0000, maka bagian masing-masing:

\begin{tabular}{|l|l|l|l|}
\hline \multicolumn{2}{|c|}{ Ahli waris } & Bagian diterima & \multicolumn{2}{c|}{ Keterangan : } \\
\hline 1 & Ibu & Rp 10.000 .000 & Bagian ibu separuh dari \\
bagian bapak.
\end{tabular}

Ketiga, Surat an-Nisa' ayat 12 yang menjelasan bagian suami dan istri. Contoh kasus, ada seorang laki-laki meninggal dunia meninggalkan istri dan saudara laki-laki. Bagiannya adalah:

\begin{tabular}{|l|l|l|l|}
\hline \multicolumn{2}{|c|}{ Ahli waris } & AM $: 4$ & \multicolumn{1}{c|}{ Bagian ahli waris } \\
\hline 1 & Istri & $1 / 4$ & 1 bagian \\
\hline 2 & Saudar $\mathrm{kk}$ & Sisa & 3 bagia \\
\hline
\end{tabular}

Penjelasan:

Bilangan 4 menjadi asal masalah, angka 4 dari penyebut bagian pasti. Misalkan harta peninggalan Rp 40.000.0000, maka bagian masing-masing:

\begin{tabular}{|c|l|l|l|}
\hline \multicolumn{2}{|c|}{ Ahli waris } & \multicolumn{1}{|c|}{ Bagian diterima } & \multicolumn{2}{c|}{ Keterangan : } \\
\hline 1 & Istri & Rp 10.000.000 & Bagian istri hanya Rp \\
2 & Saudar lk & Rp 30.000.000 & $\begin{array}{l}10.000 .000, \text { lihat bagian } \\
\text { suami. }\end{array}$ \\
\hline
\end{tabular}

Contoh kasus lain, ada seorang perempuan meninggal dunia meninggalkan suami dan saudara laki-laki . Bagiannya adalah:

\begin{tabular}{|l|l|l|l|}
\hline \multicolumn{2}{|c|}{ Ahli waris } & AM $: 2$ & \multicolumn{1}{c|}{ Bagian ahli waris } \\
\hline 1 & Suami & $1 / 2$ & 1 bagian \\
\hline 2 & Saudar lk & Sisa & 1 bagia \\
\hline
\end{tabular}

Penjelasan:

Bilangan 4 menjadi asal masalah, angka 4 dari penyebut bagian pasti. Misalkan harta peninggalan Rp 40.000.0000, maka bagian masing-masing:

\begin{tabular}{|c|l|l|l|}
\hline \multicolumn{2}{|c|}{ Ahli waris } & Bagian diterima & \multicolumn{1}{c|}{ Keterangan : } \\
\hline 1 & Suami & Rp 20.000.000 & $\begin{array}{l}\text { Bagian suami Rp 20.000.000, } \\
\text { lebih banyak dari bagian } \\
\text { istri. }\end{array}$ \\
\hline
\end{tabular}

Ketiga, Surat an-Nisa' ayat 176 menjelasan bagian saudara sekandung (perempuan dan laki-laki). Contoh kasus, ada seorang laki-laki atau 
perempuan meninggal dunia meninggalkan saudara sekandung (perempuan dan laki-laki)

\begin{tabular}{|l|l|l|l|}
\hline \multicolumn{2}{|c|}{ Ahli waris } & Asal Masalah (AM) : 3 & Bagian ahli waris \\
\hline 1 & Sdr perempuan & $\begin{array}{l}\text { Seluruh } \\
\text { harta peninggalan }\end{array}$ & 2 bagian \\
\cline { 4 - 4 } 2 & Sdr laki-laki & bagia \\
\hline
\end{tabular}

Penjelasan:

Bilangan 3 menjadi asal masalah, angka 3 dari banyaknya ahli waris perempuan dihitung seorang dan laki-laki dua orang. Misalkan harta peninggalan Rp 30.000.0000, maka bagian masing-masing:

\begin{tabular}{|c|l|l|l|}
\hline \multicolumn{2}{|c|}{ Ahli waris } & Bagian diterima & \multicolumn{2}{|c|}{ Keterangan : } \\
\hline 1 & Sdr perempuan & Rp 10.000 .000 & $\begin{array}{l}\text { Bagian saudara } \\
\text { perempuan separuh dari } \\
\text { bagian saudara laki-laki }\end{array}$ \\
\hline 2 & Sdr laki-laki & Rp 20.000.000
\end{tabular}

Dari paparan contoh di atas, menunjukkan bahwa bagian perempuan separuh dari bagian laki-laki tidak terkecuali, bagian orang tua; ibu dan bapak. Dalam kasus gharrâwain menempati kajian tersendiri dalam kajian ilmu farâid bersama beberapa kasus lain yang belum pernah terjadi dan diputuskan oleh Rasulullah saw. Masalah ini juga dinamakan umariyatain karena masalah ini baru terjadi pada masa khalifah 'Umar bin Khațâb ra dan diputuskan penyelesaiannya oleh 'Umar bin Khattâb ra. Dalam kasus ini ibu mendapat bagian sepertiga sisa ini dalam dua kasus, dan dua kasus ini yang ditetapkan oleh 'Umar bin Khațtâb sehingga dikenal dengan sebutan 'umariyatain.

Dalam teks nasss Al-Qur'an, bagian ibu adalah: 1/6 jika mayat meninggalkan anak dan dua saudar dan jika mayat tidak meninggalkan anak dan dua saudar maka bagian ibu $1 / 3$.

Contoh kasus, seorang perempuan meninggal, ahli waris : ibu, dan bapak. maka penyelesaiannya adalah:

\begin{tabular}{|c|l|l|l|}
\hline \multicolumn{2}{|c|}{ Ahli waris } & AM : 3 & Bagian ahli waris \\
\hline \hline 1 & Ibu & $1 / 3$ & 1 bagian \\
\hline 2 & Bapak & Sisa & 2 bagia \\
\hline
\end{tabular}

Penjelasan:

1. Bilangan 3 menjadi asal masalah, angka 3 tersebut dari penyebut bagian pasti.

2. Ibu mendapat bagian $1 / 3$ dan mendapatkan 1 (satu) bagian

3. Bapak mendapatkan bagian sisanya 2 (dua) bagian 
Ayat tersebut di atas, menetapkan pondasi, mengenai aturan warisan, bahwa bagian ibu setengahnya dari bagian yang diterima oleh bapak, alasannya sebab mayat tidak meninggalkan anak.

Seandainya harta peninggalan (HP) Rp 12.000.000, maka bagian ibu dan bapak adalah HP Rp 12.000.000, maka:

$$
\frac{H P . R p 12.000 .000}{A M: 3}=R p 4.000 .000
$$

\begin{tabular}{|c|c|c|c|}
\hline \multicolumn{2}{|c|}{ Ahli waris } & \multicolumn{2}{|c|}{ Bagian yang diterima oleh ibu dan bapak: } \\
\hline 1 & 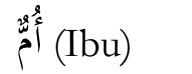 & 1 bagian x Rp 4.000 .000 & Rp 4.000 .000 \\
\hline 2 & (Bapak أُبٌْ & 2 bagian $x$ Rp 4.000 .000 & Rp 8.000 .000 \\
\hline & & Jumlah & Rp 12.000.000 \\
\hline
\end{tabular}

Dalam kasus gharrâwain ibu mendapat bagian thuluth al-bâq (sepertiga sisa) yaitu sepertiga dari harta peninggalan setelah diambil bagian suami atau istri. Bagian thuluth al-bâq tidak pernah disebutkan baik dalam AlQur'an maupun hadits. Kasus gharrâwain terjadi dalam kasus mayyit meninggalkan ahli waris suami atau istri, ibu, bapak, dan tidak ada far' (anak atau cucu), tidak meninggalkan juga saudara.

Dalam praktek perhitungan harta waris dengan bagian normal ibu, kasusnya dapat dipaparkan sebagai berikut: Seorang perempuan meninggal dunia meninggalkan ahli waris; suami, ibu, dan bapak. (Ibu bersama suami dari mayyit dan bapak). Penyelesaian pembagiannya adalah:

\begin{tabular}{|l|l|l|l|}
\hline \multicolumn{2}{|c|}{ Ahli Waris } & AM: 6 & \multicolumn{1}{c|}{ Bagian ahli waris } \\
\hline 1 & Suami & $1 / 2$ & 3 bagian \\
\hline 2 & Ibu & $1 / 3$ & 2 bagian \\
\hline 3 & Bapak & Sisa & 1 bagia \\
\hline
\end{tabular}

\section{Penjelasan:}

1. Bilangan 6 menjadi asal masalah, angka 6 dari kelipatan persekutuan terkecil (KPK) penyebut bagian pasti 2 dan 3 .

2. Ibu mendapat bagian $1 / 3$ dan mendapatkan 2 (dua) bagian

3. Bapak mendapatkan bagian sisanya 1 (satu) bagian

Dengan perhitungan di atas, ibu mendapat dua bagian sedangkan bapak mendapat satu bagian. Artinya, bagian ibu dua kali lebih besar dari pada bagian bapak. Penyelesaian tersebut tidak mengacu pada bagian bapak dua kali lebih besar dibandingkan bagian ibu (li al-dhakar mithl haz:. al-unthayain). Penyelesaian ini juga bertentangan dengan apa yang 
dijelaskan oleh Al-Qur'an surat al-Nisâ': 11 dimana ayat tersebut menetapkan asas bagi orang tua (ibu dan bapak) jika mayit tidak meninggalkan walad (anak) dan dua orang saudara, maka ibu mendapat bagian $1 / 3$ sedangkan sisanya, yaitu $2 / 3$, diberikan kepada bapak.

Kasus inilah yang menggelitik 'Umar bin Khațâb berijtihâd menyelesaikan perhitungan dengan mengacu pada bagian bapak (lakilaki) dua kali lebih besar dibandingkan bagian ibu (perempuan). Dari ijtihâd 'Umar, didapatkan bahwa perhitungan pendapatan laki-laki dua kali lebih besar dari perempuan ditemukan dengan tetap berpedoman pada angka sepertiga sebagaimana ditegaskan oleh al-Nisa: 12. Hanya saja, sepertiga yang digagas oleh shahabat 'Umar dalam kasus ini tidak menunjuk sepertiga dari seluruh harta peninggalan, tetapi sepertiga ditunjuk dengan sepertiga dari sisa harta peninggalan setelah diambil sebagai bagian suami atau istri.

Pemecahan tersebut dapat dipaparkan sebagai berikut : seorang perempuan meninggal dunia meninggalkan ahli waris; suami, ibu, dan bapak penyelesaiannya adalah sebagai berikut:

\begin{tabular}{|l|l|l|l|l|}
\hline \multicolumn{2}{|c|}{ Ahli Waris } & \multicolumn{2}{c|}{ AM : 6 } & Bagian ahli waris \\
\hline 1 & Suami & $1 / 2$ & 3 & 3 bagian \\
\hline 2 & Ibu & $1 / 3$ sisa & \multirow{2}{*}{3} & 1 bagian \\
\cline { 2 - 3 } \cline { 5 - 5 } & Bapak & Sisa & & 2 bagia \\
\hline
\end{tabular}

Penjelasan:

1. Bilangan 6 menjadi asal masalah, angka 6 dari kelipatan persekutuan terkecil (KPK) penyebut bagian pasti 2 dan 3.

2. Ibu mendapat bagian $1 / 3$ sisa dan mendapatkan 1 (satu) bagian

3. Bapak mendapatkan bagian sisanya 2 (dua) bagian

Seandainya harta peninggalan (HP) Rp 12.000.000, maka bagian ibu dan bapak adalah: HP.Rp 12.000 .000

$$
A M: 6
$$

\begin{tabular}{|c|c|c|c|}
\hline \multicolumn{2}{|r|}{ Ahli waris } & \multicolumn{2}{|c|}{ Bagian yang diterima oleh ibu dan bapak: } \\
\hline 1 & زَوْجِج (suami) & 3 bagian x Rp 2.000 .000 & Rp $\quad 6.000 .000$ \\
\hline 2 & أُ أُ & 1 bagian x Rp 2.000 .000 & Rp $\quad 2.000 .000$ \\
\hline 3 & (Bapak أَبْ (Bak & 2 bagian x Rp 2.000 .000 & $\mathrm{Rp} \quad 4.000 .000$ \\
\hline \multicolumn{3}{|c|}{ Jumlah } & Rp 12.000 .000 \\
\hline
\end{tabular}

Menetapkan bagian sepertiga yang pada hakikatnya adalah seperenam, maka perhitungan itu tidak menyalahi bagian pasti yang ditentukan oleh Al-Qur'an untuk ibu. Hanya saja, bagian sepertiga itu dialihkan 
pengertiannya dengan sepertiga dari sisa harta peninggalan, bukan sepertiga dari seluruh harta peninggalan. Dengan demikian bagian dari ibu merupakan setengah dari bagian bapak dari unsur aturan telah direspon, sebab bagian perempuan setengah dari bagian laki-laki terpenuhi, dan penetapan bagian ibu oleh ayat juga tidak dilanggar.

Melihat keadaan sebenarnya dimana mayyit tidak meninggalkan al-far' (anak) dan tidak ada ikhwah (saudara lebih dari satu), bagian ibu adalah sepertiga. Bagian sepertiga inilah yang dipakai sebagai bagian untuk ibu. Sekalipun ibu mendapat bagian sepertiga (al-thuluth) tetapi pada hakikatnya bagian ibu menjadi seperenam. Perhitungan tersebut tidak menyalahi bagian pasti yang ditentukan oleh Al-Qur'an untuk ibu. Hanya saja, bagian sepertiga itu dialihkan pengertiannya dengan sepertiga dari sisa harta peninggalan, bukan sepertiga dari seluruh harta peninggalan.

Penyelesaian ibu mendapat bagian 1/3 sisa dalam kasusu di atas itu, memberikan konsekuensi hukum bagi bapak bahwa bagian bapak adalah sisa, mengingat mayat tidak meninggalkan walad (anak). Dan bagian sisa yang terimah oleh bapak nominalnya adalah $1 / 3$ dari harta peninggalan.

\section{Thuluth al-Bâq dalam Bagian Ibu Pengertian Thuluth al-Bâq}

Thuluth al-bâq bermakna memberikan bagian kepada ahli waris bagian sepertiga setelah harta diambil sebagian untuk bagian dari ahli waris lain yang mempunyai bagian pasti. ${ }^{11}$ Istilah thuluth al-bâq tidak pernah disebut dalam nash, baik Al-Qur'an maupun hadis Nabi. Penggunaan istilah thuluth al-bâq menyesuaikan dengan firman Allah swt. dalam surat alNisâ’: 11 yang menyebut bagian ibu adalah sepertiga:

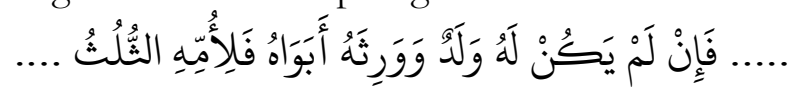

Artinya: “....jika orang yang meninggal tidak mempunyai anak dan ia diwarisi oleh ibu-bapaknya (saja), maka ibunya mendapat sepertiga..."

Munculnya istilah thuluth al-bâq berawal dari memahami al-Nisâ': 11 pada bagian waris untuk ibu. Munculnya dua kasus sebagaimana tersebut diatas, bagian ibu dipahami dengan sepertiga sisa harta, bukan sepertiga dari seluruh harta peninggalan. Pendapat ini dinisbatkan kepada beberapa

11 Syuhada Syarkun, Menguasai Ilmu Faraidh, (Jakarta: Pustaka Syarkun, 2014), 103. 
sahabat terutama 'Umar bin Khạttâb dan Zaid bin Thâbit yang kemudian diikuti oleh jumbûr ulamâ..'

Pendapat lain mengatakan bahwa bagian al-thuluth untuk ibu bermakna sepertiga dari seluruh harta peninggalan. Pendapat ini dinisbatkan kepada Ibn 'Abbâs. ${ }^{13}$ Dalam pendapat Ibn 'Abbâs ini, Ibn alQayyim menyebut riwayat tentang perdebatan Ibn 'Abbâs dengan Zaid bin Thâbit: ${ }^{14}$

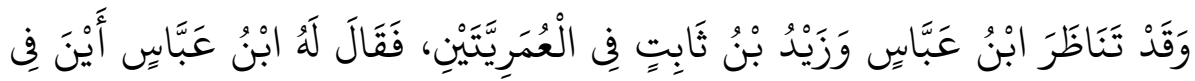

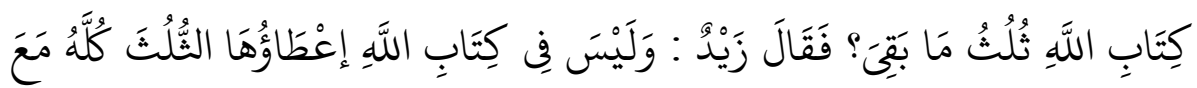

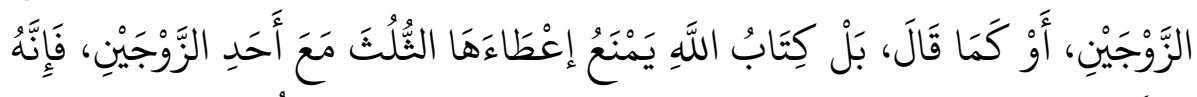

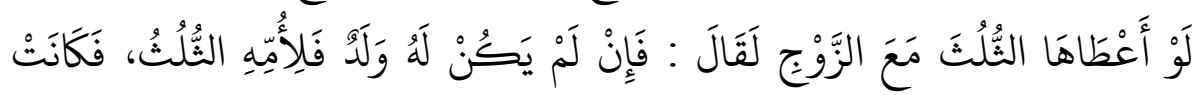



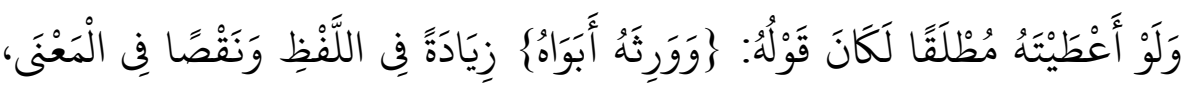

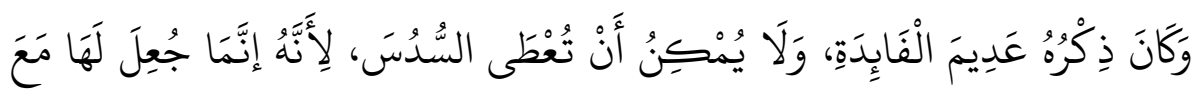

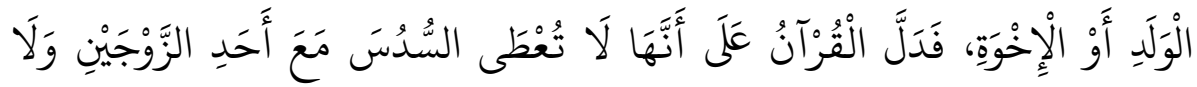

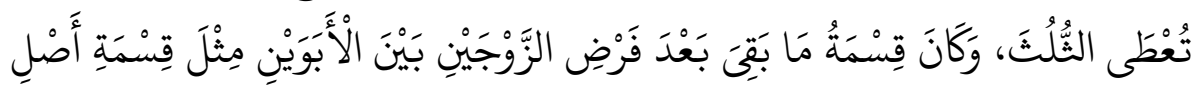

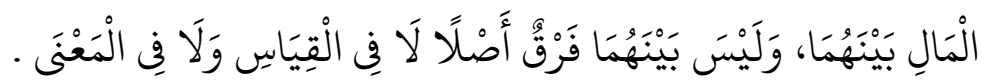

Artinya: "Ibn 'Abbâs mempertanyakan adakah dasar penetapan sepertiga sisa berdasar kitâbullâh. Zaid justru menjawab babwa dalam Al-Qur'an juga tidak terdapat petunjuk bahwa bagian ibu adalab sepertiga barta peninggalan saat bersama salah satu suami istri. Jika harus mutlak sepertiga harta, maka ayat akan berbunyi fain lam yakun walad fa li ummih al-thuluth, dan pengkbususan pemberian bagian sepertiga dalam keadan khusus menunjukkan ketidakmutlakan bagian sepertiga untuk

\footnotetext{
12 Ḥusain Yûsûf Ghazal, Al-Mîrâth 'alâ Madhâhib al-'Arba'ah (Beirut: Dar al-Fikr, 2003), 30; Aḥmad 'Abd al-Jawwad, Ușull, 41; Muhammad bin Aḥmad al-Qurtûbî, al-Jâmi' li Aḅkâm al-Qur'ân, vol. 6 (Beirut: Muassasah al-Risalah, 2006), 96.

${ }^{13}$ Lihat Sulaimân bin Khalâf, Al-Muntaqâ Sharḅ al-Munațtâ' Mâlike, vol. 6 (Beirut: Dar alFikr al-Ilmiah, 1999), 225.

${ }^{14}$ Muhạmmad bin Abî Bakr Ibn Qayyim al-Jawzî, I'lâm al-Munâqi'in 'an Rabb al-'Alamîn, vol. 1 (Beirut: Dar al-Kutub al-'Ilmiyyah, t.th.), 496.
} 
ibu. Demikian juga jika bagian sepertiga itu adalah mutlak, maka penyebutan kata dalam wa waritsabu abawah dalam ayat menjadi bampa makna. Tidak juga ibu bisa mendapat bagian seperenam yang menjadi bagiannya saat bersama anak atau saudara lebih dari satu. Al-Qur'an juga menunjukkan bahwa bagian ibu seperenam maupun sepertiga tidak. ada saat bersama salah satu suami istri sehingga bagian sisa setelah diberikan kepada suami untuk ibu dan bapak adalah sebagaimana bagian sebenranya bagi mereka (bapak-ibu, laki-laki perempuan) dan tidak ada perbedaan apapun baik dalam qiyas maupun dalam maknanya."

Istilah thuluth al-bâq kemudian populer dalam ilmu farâid sebagaimana tertuang dalam literatur tentang bagian ibu dalam waris seperti: ${ }^{15}$

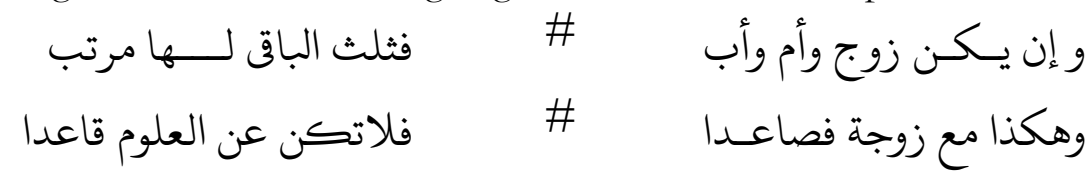

"Apabila dalam pembagian harta peninggalan ada suami, ibu dan bapak, maka bagian ibu sepertiga sisa. Demikian juga apabila bersama seorang istri atau lebih, maka tidak ada satupun kaidah dari pengetahuan yang dapat dibenarkan)"

\section{Dasar Perhitungan Thuluth al-Bâq dalam Gharrâwain}

Mencermati perdebatan Ibn 'Abbâs dan Zaid bin Thâbit atas ijtihad 'Umar, perhitungan bagian thuluth al-bâq untuk ibu dalam kasus gharrâwain mendasarkan pada beberapa dalil:

Pertama, dalam ilmu farâ'id dikenal aturan apabila terdapat ahli waris yang tingkatannya sama dengan jenis kelamin yang berbeda, maka bagian perempuan separuh dari bagian laki-laki. Pada kasus ini jika dalam perhitungan ibu memperoleh bagian sepertiga dari seluruh harta, bukan dari sepertiga sisa harta setelah diambil bagian suami atau istri, maka perhitungannya tidak sesuai dengan aturan dua berbanding satu untuk laki-laki dan perempuan.

Kedua, bapak dan ibu dengan anak laki-laki dan anak perempuan mempunyai kesamaan jenis dalam kajian ilmu farầid sebagai al-as dan alfar'. Artinya, jika ada ibnun dan bintun secara bersama-sama dan ada suami, maka mereka menerima bagian sisa setelah diambil bagian suami. Bagian sisa setelah diambil sebagai bagian suami itu dibagi tiga dimana satu bagian sebagai bagian bintun dan dua bagian sebagai bagian ibnun. Dalam aturan ini berlaku perbandingan dua banding satu untuk laki-laki

${ }^{15}$ Muṣtâfâ, Al-Rahâbiyyah 'Ilm Farâid, (Damaskus: Dar al-Qalam, 2004), 57. 
perempuan untuk sektor al-far'. Maka, aturan tersebut juga berlaku untuk bapak-ibu untuk sektor al-ashl. Demikian juga bila bersama istri.

Ketiga, apabila dalam pembagian harta peninggalan hanya ada bapak dan ibu, maka menurut nass ayat Al-Qur'an bagian yang diterima ibu tetap separo dari bagian yang diterima bapak. Demikian juga apabila hanya ada bapak dan ibu bersamaan salah satu suami istri. ${ }^{16}$

Ibn al-Qayyim dalam hal ini menyatakan: ${ }^{17}$

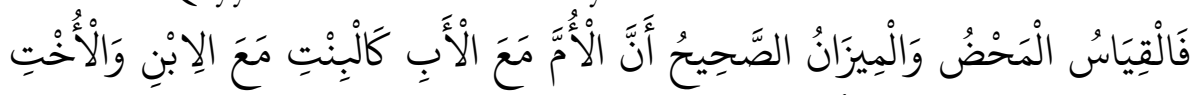

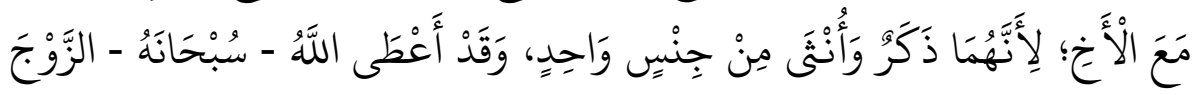



Artinya: "Ini adalab murni qiyas dan ukuran yang tepat dimana ibu dengan bapak adalah sebagaimana anak perempuan dengan anak laki-laki dan saudara perempuan dengan saudara laki-laki sebab ibu dan bapak. sebagai laki-laki dan perempuan adalah dalam jenis yang sama (dengan anak perempuan dengan anak laki-laki dan saudara perempuan dengan saudara laki-laki dalam jenis hal laki-laki dan perempuan). Allah juga memberikan bagian suami dua kali bagian perempuan berdasar atas kelelakiannya."

\section{Analisa}

Kepiawaian Zaid dalam hal ilmu farâi ị disebut oleh sahabat 'Umar dalam pidatonya ketika menjadi khalifah sebagaimana disebut oleh Ibn al-Qayyim. Kehebatan Ibn 'Abbâs akan pemahaman Al-Qur'an didukung oleh do'a Nabi atasnya.

Dalam pidatonya, 'Umar bin Khațtâb menunjuk: ${ }^{18}$

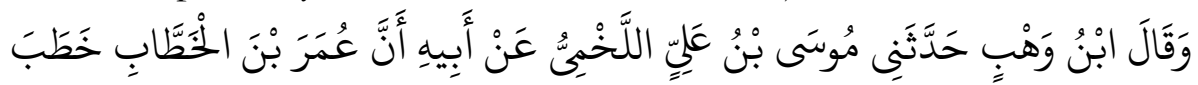

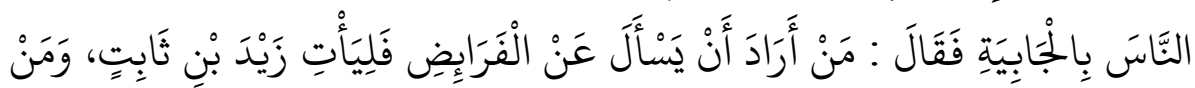



Artinya: "Siapa yang hendak bertanya tentang faraidl, datanglah kepada Zaid bin Tsâbit. Yang ingin bertanya tentang fiqh, datangilah Muadz bin Jabal. Dan barang siapa yang menginginkan harta, datanglah kepadaku."

\footnotetext{
${ }^{16}$ Syuhada Syarkun, Menguasai, 103.

17 Al-Jawzî, I'lâm, vol. 1, 489.

18 Al-Jawzî, I’lâm, vol. 1, 23.
} 
Sementara do'a Rasul untuk Ibn 'Abbâs sebagaimana disebut dalam Târî̉h al-Qur'ân al-Karîm: ${ }^{19}$

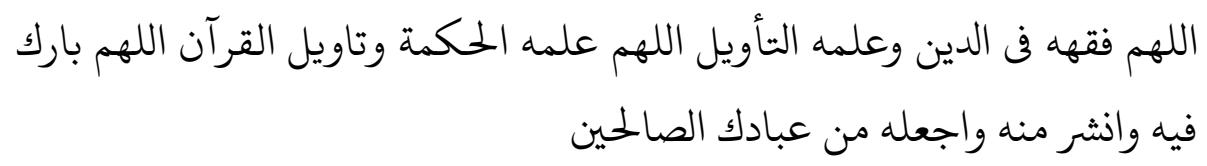

Artinya: "Ya Allah, pabamkan dia akan agama dan jadikanlah dia jenius dalam ta'wîl. Ya Allah, jadikanlah dia alim dalam bikmah dan ta'wîl qur'ân. Ya Allah, berkabilah kebebatannya dan menjadi sumber ilmu, dan jadikanlah dia hamba-Mu yang shalih."

Pengakuan-pengakuan di atas, menunjukkan betapa mendalamnya keilmuan keduanya. Penunjukan kejeniusan pemahaman akan dalil agama tidak serta merta menyatukan Zaid dan Ibn 'Abbâs dalam satu pandangan yang persis sama. Keduanya memiliki ruang ijtihad yang dalam hasil berbeda sekalipun bisa saling menghormati. Hasil ijtihad tentang bagian sepertiga untuk ibu dimana Zaid bin Thâbit ada dalam satu pendapat dan Ibn 'Abbâs ada dalam pendapat lain yang berbeda berimplikasi bahwa ruang ijtihâd selalu terbuka.

Dalam pendapat Umar yang dikenal dengan gharâwain, bagian ibu sepertiga sisa dapat diterapkan dalam keadaan biasa sehingga saat ibu menerima setengah dari bagian bapak tidak terjadi masalah. Keadaan biasa yang dimaksud adalah kedua bapak ibu dalam keadaan terikat perkawinan dan kondisi kebutuhan (terutama ekonomi) tercukupi. Dalam keadaan lain, misalnya, bapak dan ibu sudah hidup terpisah sebab tidak terikat dalam ikatan perkawinan, keadaan usia yang tidak produktif, ditambah dari sektor ibu tampak lebih membutuhkan sumber ekonomi, maka pendapat Ibn 'Abbâs yang memberikan bagian ibu sepertiga dari seluruh harta peninggalan dapat diterapkan.

Bagian laki-laki perempuan dalam skala perbandingan dua banding satu yang dipahami sebagai batas atas dan batas bawah ${ }^{20}$ menemukan penguatnya dalam kasus gharrâwain dari pendapat Ibn 'Abbâs. Perbandingan tersebut dipahami dengan laki-laki dapat menerima bagian waris maksimal dua kali bagian perempuan, dan perempuan dapat menerima bagian minimal satu bagian dari laki-laki. Menggunakan pendapat Ibn 'Abbâs, bagian sepertiga untuk ibu bersama suami dan bapak, ibu (perempuan) diberikan bagian sepertiga dari seluruh harta peninggalan pendapatan maksimalnya adalah dua kali bagian bapak (laki-

\footnotetext{
19 Al-Jawzî, I'lâm, vol. 1, 18

${ }^{20}$ Muhammad Shahrûr, Naḅv Usû́l al-Jadîdah li al-Fiqh al-Islâmî (Damaskus: al-Ahali li alTiba'ah wa al-Nashr, 2000), 232.
} 
laki). Dan pada kasus kedua saat ibu bersama istri dan bapak, pendapatan maksimal ibu adalah hampir sama dengan bagian bapak (laki-laki).

Bagian ibu (perempuan) pada kasus pertama dengan menggunakan perhitungan Ibn 'Abbâs yang memberikan sepertiga dari seluruh harta peninggalan tidak keluar dari batas maksimal bagian ibu (perempuan) yang dimungkinkan dapat mencapai dua bagian, sama dengan pendapatan bapak. Bagian ibu (perempuan) dalam kasus kedua dengan memberikan sepertiga seluruh harta peninggalan masih ada di bawah bagian bapak (laki-laki), hanya saja tidak bagian ibu bukan setengah dari bagian bapak. Begitu pun bagian bapak sebagai laki-laki tidak keluar dari bagian yang dimungkinkan, minimal satu dan makisaml dua. Keduanya tidak melampaui batas maksimal dan minimal pada bagian yang dimungkinkan untuk masing-masing ibu dan bapak sebagai laki-laki dan perempuan.

\section{Kesimpulan}

Dari paparan bahasan persoalan bagian waris ibu sepertiga yang dipahami dengan sepertiga seluruh harta peninggalan dan sepertiga sisa harta peninggalan setelah diambil sebagai bagian pasti untuk suami, persoalan ini muncul dalam skema ijtihadiyah. Darinya dapat diambil simpulan:

Pertama, petunjuk Al-Qur'an mengenai waris sudah sebegitu baku dan tawqifiyat. Akan tetapi masih sangat terbatas dan berupa petunjuk global. Penunjukan aturan dalam keadaan global memberi ruang terbuka untuk melakukan ijtihad.

Kedua, dalam kasus bagian ibu saat bersama bapak dan salah satu suami atau istri yang belum pernah terjadi pada masa Rasul menyebabkan 'Umar bin Khạttâb sebagai khalifah harus berijtihad untuk memberi jawaban penyelesaian. Kasus ini yang kemudian dikenal sebagai gharrâwain atau umariyatain.

Ketiga, dengan keputusan umariyatain bagian ibu dapat diselesaikan dengan tetap mempertahankan skala dua berbanding satu untuk laki-laki dan perempuan dengan mengarahkan pemahaman bahwa bagian sepertiga ibu pada kondisi itu adalah sepertiga sisa harta, bukan sepertiga seluruh harta peninggalan. Akan tetapi, saat posisi bapak tidak ada sementara kakek (orang tua bapak) masih ada dan menggantikan posisi bapak dalam pewarisan ibu tetap mendapatkan bagian sepertiga dari seluruh harta peninggalan karena kakek (meskipun laki-laki) tidak sederajat dengan ibu dalam pewarisan. 
Keempat, pembagian dua banding satu untuk laki-laki dan perempuan dalam waris yang dipahami dengan laki-laki dapat menerima bagian waris maksimal dua kali bagian perempuan, dan perempuan dapat menerima bagian minimal satu bagian dari laki-laki dengan perhitungan menurut Ibn 'Abbâs dalam kasus gharawain tidak keluar dari bagian yang dimungkinkan, yaitu minimal satu dan makismal dua untuk masingmasing ibu dan bapak sebagai laki-laki dan perempuan.

Kelima, bagian ibu sepertiga sisah setelah diambil bagian suami dalam kasus di atas adalah memberikan aturan hukum dan konsekuensi terhadap bagian bapak menjadi 1/3 sekalipun disebut mendapat bagian sisa $(t a ’ s i \hat{\imath})$.

\section{Daftar Pustaka}

Anșârî (al), Zakariyâ. Șaṛ al-Tahrîr. Surabaya: Maktabat Salim b. Sa'ad b. Nabhan, t.th.

Ghazal, Husain Yûsûf. Al-Mîrath 'alâ Madhâhib al-'Arba'ah. Beirut: Dar alFikr, 2003.

Jawad (al), Aḥmad 'Abd. Usûul al-Ilm al-Mawârith. Beirut: Dar al-Jayl, 1986. Cet. II.

Jawzî (al), Muḥammad bin Abî Bakr Ibn Qayyim. I'lâm al-Muwâqi’in 'an Rabb al-'Alamin. Beirut: Dar al-Kutub al-'Ilmiyyah, t.th. Vol. I.

Khalaf, Sulaiman bin. Al-Muntaqâ Sharh al-Muwattâ’ Mâlike. Beirut: Dar alFikr al-Ilmiah, 1999. Vol. VI.

Muștafâ. Al-Rabâbiyyah Tlm Farâid. Damaskus: Dar al-Qalam, 2004.

Qurțîbî (al), Muhammad bin Aḥmad. Al-Jâmi' li Aḅkâm al-Qur'ân. Beirut: Muassasah al-Risalah, 2006. Vol. VI.

Ruslan, Muhammad Jumalî. Risâlah fi Fiqh al-Mawârith. Tebuireng: Mathba'ah Tifaza, t.th.

Shahrûr, Muhammad. Naḥw Usûul al-Jadîdah li al-Fiqh al-Islâmî. Damaskus: al-Ahali li al-Tiba'ah wa al-Nashr, 2000.

Syarkun, Syuhada'. Menguasai Ilmu Faraidh. Jakarta: Pustaka Syarkun, 2014.

Wahiiî (al), 'Alî Ibn Aḥmad. Asbâb al-Nuzûul. Beirut: 'Alam al-Kutub, t.th. 